\title{
TINGKAT KEMAMPUAN MEMBACA BAHASA INGGRIS MAHASISWA SEMESTER 2 JURUSAN ADMINISTRASI NIAGA POLITEKNIK NEGERI JAKARTA
}

\author{
Supriatnoko ${ }^{1, \varpi)}$, Anwar Mustofa ${ }^{2)}$ \\ Politeknik Negeri Jakarta. \\ e-mail : ${ }^{1}$ supriatnoko@gmail.com,${ }^{2}$ anwar.mustofa@bisnis.pnj.ac.id
}

\begin{abstract}
This study aims to obtain fact about the level of reading skills of high school graduates who continue their studies at State Polytechnic of Jakarta level one, in terms of reading skills aloud and understanding the content of their reading shown by the use of word types and in arranging sentences that are correct in grammar. The benefit of this research is to improve the reading skills of learning techniques that lead to comprehensive competencies for specific skills that shape the integrity of the reading skill competencies, namely the ability to read aloud and the comprehension of reading contents. This research uses a qualitative approach. The class sample is assigned 4 classes, namely 2 classes from D-3 Business Administration Study Program, 1 class from D-4 Applied Business Administration Study Program, and 1 class from MICE Study Program, determined based on purposive sampling method. Research subjects were students who were registered in the sample class. Data were collected using written test techniques including material to understand reading content consisting of introduction to types of words, composing sentences to answer questions and reading test aloud. The collected data is then discussed and analyzed, measured based on predetermined scores and indicators. From the data discussed and analyzed, it can be found that the average reading aloud test result is 65.6 and the average test comprehends the reading content of 75.1. Based on indicators of reading aloud test, it can be concluded that the level of reading skill reached by the senior high school graduates, are substandard, inaccurate, and unclear. Based on the indicators understanding the contents of the reading, it can be concluded that the level of skill in understanding the content of reading achieved are the correct answer but found grammatical errors.
\end{abstract}

Keywords : reading aloud, reading for understanding, level of reading skills

\begin{abstract}
ABSTRAK
Penelitian ini bertujuan untuk mengetahui fakta tentang tingkat keterampilan membaca lulusan SMA yang melanjutkan studi di Politeknik Negeri Jakarta tingkat satu, dalam hal keterampilan membaca nyaring dan pemahaman isi bacaan yang ditunjukkan dengan penggunaan jenis kata dan dalam menyusun kalimat yang benar dalam tata bahasa. Manfaat penelitian ini adalah untuk meningkatkan keterampilan membaca teknik pembelajaran yang mengarah pada kompetensi komprehensif untuk keterampilan khusus yang membentuk integritas kompetensi keterampilan membaca, yaitu kemampuan membaca nyaring dan pemahaman isi bacaan. Penelitian ini menggunakan pendekatan kualitatif. Sampel kelas ditetapkan 4 kelas, yaitu 2 kelas dari Program Studi D-3 Administrasi Bisnis, 1 kelas dari Program Studi D-4 Administrasi Bisnis Terapan, dan 1 kelas dari Program Studi MICE, ditentukan berdasarkan metode purposive sampling. Subjek penelitian adalah siswa yang terdaftar di kelas sampel. Pengumpulan data dilakukan dengan teknik tes tertulis meliputi materi memahami isi bacaan yang terdiri dari pengantar jenis kata, menyusun kalimat menjawab pertanyaan dan tes membaca nyaring. Data yang terkumpul kemudian dibahas dan dianalisis, diukur berdasarkan skor dan indikator yang telah ditentukan. Dari data yang didiskusikan dan dianalisis, diketahui bahwa rata-rata hasil tes membaca nyaring adalah 65,6 dan tes rata-rata memahami isi bacaan sebesar 75,1. Berdasarkan indikator tes membaca nyaring, dapat disimpulkan bahwa tingkat keterampilan membaca yang dicapai oleh lulusan SLTA, kurang lancar, tidak akurat, dan tidak jelas. Berdasarkan indikator pemahaman isi bacaan, dapat disimpulkan bahwa tingkat keterampilan memahami isi bacaan yang dicapai jawaban benar tetapi ditemukan kesalahan tata bahasa.
\end{abstract}

Kata kunci : membaca nyaring, membaca untuk memahami, tingkat kemampuan membaca 


\section{PENDAHULUAN}

Membaca merupakan salah satu keterampilan atau kemahiran bahasa Inggris di samping berbicara, menulis, dan menyimak. Keterampilan membaca termasuk salah satu jenis keterampilan berbahasa Inggris yang harus dikuasai seorang pemelajar. Oleh sebab itu, keterampilan membaca menjadi salah satu syarat seseorang yang dikatakan terampil berbahasa Inggris.

Atas dasar pentingnya keterampilan membaca bagi pemelajar yang sedang belajar bahasa Inggris, maka setiap pembelajaran bahasa Inggris baik di tingkat sekolah menengah pertama, sekolah menengah atas maupun di perguruan tinggi diberikan materi membaca. Meskipun isi materi bacaan bervariasi, tujuan utamanya adalah supaya pemelajar mampu memahami isi teks yang dibaca. Di samping itu, pemelajar juga memahami bagaimana membaca huruf dengan bunyi yang benar, mengerti bagaimana mengucapkan kata dan kalimat dengan nada, tekanan yang benar dan tepat, memahami bagaimana menyusun kalimat yang menjawab pertanyaan. Ketepatan pengungkapan gagasan harus didukung dengan ketepatan bahasa yang digunakan, kosakata dan tata bahasa serta penggunaan ejaan.

Mencermati kemajuan hasil belajar bahasa Inggris pemelajar Semester 2 Jurusan Administrasi Niaga yang lebih menekankan pembelajarannya pada praktik berbicara dan menulis bahasa Inggris, muncul pertanyaan apakah mereka juga dapat dikatakan memiliki keterampilan membaca yang memadai khususnya pada praktik membaca nyaring dan cepat serta membaca untuk pemahaman.

Pada pembelajaran bahasa Inggris yang terintegrasi, keterampilan membaca merupakan keterampilan yang wajib diberikan secara terstruktur kepada pemelajar yang belajar bahasa Inggris sebagai bahasa asing, sebab mereka memiliki waktu belajar bahasa Inggris yang terbatas hanya selama waktu pelajaran bahasa di kelas, tidak seperti mahasiswa di negara-negara yang memperlakukan bahasa Inggris sebagai bahasa kedua. Mereka memiliki ruang yang luas untuk mempraktikkan bahasa yang dipelajari di lingkungan sosial masyarakat dan dalam kegiatan pemerintahan. Alasan lain bahwa keterampilan membaca wajib diajarkan di kelas karena pemelajar Indonesia malas melatih diri alih-alih mempraktikkan materi yang diterima dari setiap hasil belajar bahasa Inggris di kelas. Mereka merasa bahwa bahasa Inggris belum menjadi kebutuhan.

\section{METODE PENELITIAN}

Penelitian ini mengambil tempat di Jurusan Administrasi Niaga Politeknik Negeri Jakarta dan dilaksanakan selama 6 bulan (Mei s.d. Nopember 2019). Populasi penelitian ini adalah seluruh mahasiswa semester 2 Jurusan Administrasi Niaga Program Studi D3 Administrasi Bisnis, D4 Administrasi Bisnis Terapan, dan D4 MICE. Terdapat 4 kelas di Program Studi D3 Administrasi Bisnis dan 2 kelas di Program Studi D4 Administrasi Terapan, dan 3 kelas di Program Studi MICE.

Sampel dalam penelitian ditetapkan sebanyak 4 kelas atau setara dengan jumlah mahasiswa sebanyak 105 orang, yaitu 2 kelas dari D3 Administrasi Bisnis (51 orang), 1 kelas dari D4 Administrasi Bisnis Terapan (28 orang), dan 1 kelas dari D4 MICE (26 orang). Sampel kelas diambil secara acak. Subjek penelitian adalah mahasiswa yang terdapat di kelas-kelas sampel.

Data penelitian dikumpulkan dengan menggunakan teknik tes tertulis dan tes membaca nyaring. Data yang telah terkumpul dari tiap item tes dihitung dan dicarikan nilai rata-ratanya diukur kebenarannya dengan menggunakan 
indikator penilaian dan skor yang ditetapkan sebelumnya. Indikator penilaian untuk hasil tes membaca nyaring dan cepat, indikator penilaian untuk pemahaman mahasiswa terhadap isi bacaan dan keterampilan menyusun kalimat jawaban.

\section{HASIL DAN PEMBAHASAN}

Populasi penelitian ini adalah seluruh mahasiswa semester 2 Jurusan Administrasi Niaga Program Studi D3 Administrasi Bisnis, D4 Administrasi Bisnis Terapan, dan D4 MICE. Secara keseluruhan, terdapat 245 mahasiswa yang terbagi atas 41 mahasiswa pria atau sebanyak $17 \%$ dan mahasiswa wanita sebanyak 204 atau sebanyak 83\%. Di Jurusan Administrasi Niaga secara keseluruhan terdapat 9 kelas yang terdiri dari 4 kelas Program Studi D3 Administrasi Bisnis, 2 kelas Program Studi D4 Administrasi Terapan, dan 3 kelas Program Studi MICE.

Sampel penelitian sebanyak 105 orang atau sebanyak 43\%. Sampel diambil secara acak. Sampel mahasiswa pria sebanyak 14 orang atau $13 \%$ dari jumlah sampel keseluruhan, sedangkan sampel mahasiswa wanita sebanyak 91 orang atau $87 \%$. Adapun perbandingan jumlah populasi dan sampel dapat dilihat pada tabel 3.

Berdasarkan asal sekolah, perbandingan jumlah mahasiswa yang berasal dari sekolah menengah umum dan sekolah menengah kejuruan adalah eperti pada grafik 2.

Responden penelitian yang berasal dari Sekolah Menengah Umum sebanyak 83 orang atau (79\%) dan Sekolah Menengah Kejuruan sebanyak 22 orang atau sebanyak (21\%). Hal ini berarti sebagian besar mahasiswa yang kuliah di Jurusan Administrasi Niaga adalah mahasiswa yang berasal dari Sekolah Menengah Umum.

Berdasarkan lokasi sekolah, perbandingan jumlah mahasiswa yang berasal dari sekolah di Jakarta dan sekolah di luar Jakarta adalah seperti pada Grafik 3.

Perbandingan antara mahasiswa yang bersekolah di Jakarta dan luar Jakarta dapat dikatakan seimbang. Yang dimaksud dengan "Luar Jakarta” adalah mahasiswa yang bersekolah di luar wilayah ibu kota. Berdasarkan survey, 48\% mahasiswa responden ternyata bersekolah di Jakarta, sedangkan 52\% mahasiswa responden bersekolah di sekitar Jakarta seperti Depok, Bekasi, Bogor, Tangerang. Namun, dari 52 persen mahasiswa yang bersekolah di luar Jakarta, terdapat kurang dari 10 mahasiswa yang bersekolah di luar daerah ibu kota Jakarta, Bogor, Tngerang, Depok, dan Bekasi.

Responden pada umumnya tidak pernah mengikuti kursus atau belajar bahasa Inggris (57\%) atau sebanyak 60 orang. Namun, di antara mahasiswa yang pernah mengikuti kursus, mereka mengikutinya antara 6 bulan sampai 3 tahun.

Evaluasi Kompetensi Membaca Mahasiswa Semester 2 Jurusan Administrasi Niaga Pada Pengajaran Bahasa Inggris

\section{Kemampuan Mengeja}

Berdasarkan uji presentasi mahasiswa untuk mendeskripsi anggota keluarga di mana salah satunya adalah mengeja nama-nama anggota keluarganya, pada umumnya mahasiswa Jurusan Administrasi Niaga mampu untuk mengeja berbagai huruf dalam bahasa Inggris. Hanya sekitar 18 persen saja mahasiswa masih gagal membedakan "J" vs "G", "H”, dan "Z". Ada beberapa orang mahasiswa melafalkan “ji” untuk "J” maupun "G". Sekitar 5 mahasiswa melafalkan "eih" untuk "H” dan "zi” untuk "Z". Mahasiswa mungkin berpikir "eijh" mirip dengan "eight $=8$ ") sehingga mengucapkannya menjadi “eih". Begitu pula ketika akan mengucapkkan “zet” untuk “Z”, mereka ragu apakah ada kesamaan 
antara "zet" bahasa Indonesia dan bahasa Inggris.

Beberapa mahasiswa masih ragu mengucapkan "A", "E”, dan "I". Ragu artinya mahasiswa sewaktu mengucapkan "A", "E", dan "I" melambatkan pengucapan (vokal) ejaannya. Mahasiswa seringkali tertukar mengucapkan "e" untuk "E" dan melafalkan "i" untuk "I". Jadi, mirip pengucapannya dengan bahasa Indonesia

2. Kemampuan Mengucapkan Kata dan Frasa

Mahasiswa diminta untuk membaca nyaring 3 teks bacaan berisi sekitar 45 paragraf. Setiap paragraph berisi antara 4-7 kalimat. Teks bacaan berkaitan dengan bisnis. Teks bacaan yang pertama adalah The difference between Administration and Management. Teks bacaan yang kedua berjudul Records versus. Documents, sedangkan yang ketiga berjudul Types of Financial Statement.

Kemampuan mahasiswa mengucapkan (melafalkan) "kata" secara umum sudah baik. meskipun mereka kurang memperhatikan 'tekanan kata' (stressed words).

Dalam hal mengucapkan frasa yang memiliki fungsi dalam struktur kalimat, pada umumnya mahasiswa masih lemah. Hal ini mungkin karena teks bacaanya berkaitan dengan bisnis. Mereka belum terbiasa dengan isi bacaan yang terkait dengan bisnis. Mereka belum membuat penjedaan dengan benar. Karena membaca frasanya juga masih lemah, akibatnya intonasi dan irama bacaan mereka juga kurang tepat. Terutama, ketika mengakhiri sebuah kalimat, ketika mahasiswa diduga tidak tahu arti suatu kata, atau ketika tanda baca titik terletak di kata pertama baris berikutnya, intonasi bacaan masih naik padahal seharusnya turun. Namun, kecepatan membaca mahasiswa (fluency) secara umum sudah lancer.

Mahasiswa pria pada umumnya kurang mampu membaca dibanding mahasiswa wanita. Hal ini terjadi karena jumlah mahasiswa pria yang sedikit antara 10-17\% dari keseluruhan mahasiswa sehingga mereka kurang termotivasi untuk belajar di antara mayoritas mahasiswa wanita. Mahasiswa pria merupakan minoritas di Jurusan Administrasi Niaga.

3. Kemampuan Mengidentifikasi Jenis Kata

Meski mahasiswa mampu membaca teks, tetapi pada umumnya mahasiswa tidak tahu jenis kata. Mereka memang tahu subjek dan predikat, tetapi mereka tidak menyadari bahwa jenis kata yang mengisi gatra subjek, misalnya, harus kata benda dan jenis kata yang mengisi gatra predikat harus kata kerja. Hal ini terjadi mungkin karena frasa subjek seringkali terdiri lebih dari 2 kata (noun identifier, noun modifier, dan noun: adverb of manner, atau adjective, atau noun). Adjective juga banyak ragamnya seperti adjective yang menunjukkan kebangsaan.

Dari 10 soal yang diminta untuk mengubah jenis kata yang berasal dari 5 soal di tiap quiz, mahasiswa ratarata hanya mampu mengerjakan 3 perubahan jenis kata secara benar atau hanya sekitar 30 persen saja mereka mampu mengerjakan. Dalam kuis yang ke-1, mahasiswa sebagian tidak tahu bahwa difference (noun) akan berubah menjadi differ (verb), dan different (adjective). Mahasiswa sebagan besar tidak tahu bahwa administration (noun) berubah menjadi administer sebagai verb (mereka mengira bahwa bentuk verbnya adalah administrate) tetapi mahasiswa tahu administrative adalah bentuk adjective-nya. Mahasiswa 
sebagaian tahu direct (verb) berubah menjadi direction (noun) dan directive (adjective). Mahasiswa tahu bahwa perform (verb) berubah menjadi performance (noun) tetapi tidak tahu berubah menjadi performed sebagai adjective. Mahasiswa tidak tahu bahwa elaborate (verb) berubah menjadi elaboration (noun) dan elaborative (adjective).

Dalam kuis yang ke-2, Mahasiswa tidak tahu bahwa comprehensive (adjective), berubah menjadi comprehend (verb), tetapi rata-rata mahasiswa tahu bahwa bentuk kata bendanya adalah comprehension. Sebagian mahasiswa tahu kata maintenance (noun) akan berubah menjadi maintain (verb), tetapi tidak ada yang tahu akan berubah menjadi maintained (adjective). Mahasiswa juga tidak tahu kata prove (verb) akan berubah menjadi proof (noun), dan proven (adjective). Mahasiswa juga tidak tahu Kata apparent (adjective) akan berubah menjadi appear (verb) dan appearance (noun).

Dalam kuis yang ke-3, mahasiswa tidak tahu kata specific (adjective) harus berubah menjadi specification (noun), dan specify untuk bentuk verb. Sebagian mahasiswa tahu kata statement (noun) akan berubah menjadi state (verb), dan berubah menjadi stated (adjective). Mahasiswa tidak tahu bahwa kata expenses (noun) berubah menjadi expand (verb), dan expensive (adjective). Mahasiswa sebagian tahu bahwa kata finance (verb) berubah menjadi financing (noun) meskipun finance adalah juga benar tetapi mereka tahu financial sebagai bentuk adjectivenya.

4. Kemampuan Kosa Kata

Berkaitan dengan antonim dan sinonim, $80 \%$ mahasiswa dapat menjawab dengan benar. Artinya, dari 5 soal antonim dan 5 soal sinonim atau 10 soal keseluruhan yang diberikan, mahasiswa dapat menjawab 8 soal dengan benar. Misalnya dalam kuis ke-1, sinonim dari "process" adalah "systematic way of doing things", sinonim "accomplishment" adalah "finished", sinonim "elaborate" adalah "detail”, sinonim "controlling take into account”, dan sinonim "distinction" adalah "difference”. Berkaitan dengan antonim atau lawan kata, mahasiswa tahu bahwa lawan kata "clear" adalah "unclear". Namun, mahasiswa tidak tahu bahwa lawan kata "in advance" adalah "before". Mahasiswa juga tahu bahwa lawan kata "increase" adalah "decrease", lawan kata "traditional" adalah "modern", dan lawan kata "include" adalah "exclude".

Dalam kuis yang ke-2, mahasiswa tahu bahwa sinonim "event” adalah "phenomenon", sinonim "preserved" adalah "maintained", sinonim "truth" adalah "fact", sinonim "retain" adalah "maintain", meskipun tidak tahu sinonim "clerk" adalah "records repository". Mahasiswa tidak tahu atau barangkali lupa bahwa lawan kata "receive" adalah "spend". Mahasiswa menjawab "produced" atau "created" sebagai lawan kata "receive". Namun, mahasiswa tahu bahwa lawan kata "distinct" adalah "clear", lawan kata "centralized location" adalah "decentralized location", lawan kata "optimum" adalah "minimum", dan lawan kata "distinguish" adalah "same".

Dalam kuis yang ke-3, mahasiswa tahu bahwa sinonim "income statement" adalah "profit and loss statement”. Namun, mahasiswa tidak tahu bahwa sinonim "positive cash flows" adalah "maximize-long term free cash flow". Mahasiswa juga tahu bahwa sinonim "net earnings" adalah "revenue", sinonim "money received by the business" adalah "revenue", dan "money paid by the business" adalah "cash payment/disbursement". 
Dalam kuis yang ke-3, mahasiswa tahu bahwa lawan kata "own” adalah "owe", lawan kata "revenue" adalah "expenditure", lawan kata "gains" adalah "loss", lawan kata "profit" adalah "loss", tetapi hanya sebagian mahasiswa saja yang tahu bahwa lawan kata "a given period" adalah "long-term free cash flow".

5. Kemampuan Menjawab Soal Essay Terkait dengan pertanyaan essay, dari 5 pertanyaan essay di tiap kuisnya, mahasiswa mampu menjawab pertanyaan essay atau teks. Artinya mahasiswa mengetahui isi bacaan atau teks, akan tetapi cara mereka menjawab tidak sesuai dengan konstruksi kalimat pertanyaannya. Mahasiswa seringkali kesulitan untuk merangkai kalimatnya sehingga mereka hanya menekankan pada adanya jawaban bukan pada ketepatan jawaban.

Dalam kuis yang ke-1, dari 5 pertanyaan essay [(1): What is the traditional meaning of management?, 2) Who gave a clearer definition of management?, 3) Mention some management activities you know!, 4) What is the difference between management and administration?, 5) Why is there no more difference between management and administration], mahasiswa tidak tepat dalam menjawab pertanyaan nomor 4 dan 5. Artinya, mahasiswa masih menekankan atau berfokus pada 'yang penting menjawab'. Mahasiswa dapat menjawab pertanyaan nomor 1-3 dengan mudah. Hal ini barangkali karena pertanyaan nomer 4 dan 5 adalah pertanyaan yang berkaitan dengan menguji kemampuan 'analisis dan sintesis' mahasiswa sebagai peserta didik. Kemampuan 'analisis dan sintesis' dapat dianggap sebagai kemampuan puncak dalam memahami isi bacaan.
Dalam kuis ke-2, dari 5 pertanyaan essay yang diajukan: [(1) What is records?, 2) Why

should record be preserved in an organization?, 3) Where does the word "document" come from?, 4) How records be stored?, 5) Where does records be stored?], maka mahasiswa akan sulit menjawab pertanyaan dengan tepat jika pertanyaan dimulai dengan 'why'. Artinya dari 5 pertanyaan, hanya 1 pertanyaan soal yang jawaban tidak akurat.

Dalam kuis ke-3, dari 5 pertayaan yang diajukan [1) How many types of financial statement are there?, 2) What is balance sheet?, 3) How does a market analyst evaluate a company's financial health?, 4) What type of financial statement focuses on the company's revenues and expenses during a particular period?, 5) Who audit financial statement of an organization?], mahasiswa kesulitan untuk menjawab pertanyaan nomor 4 karena mahasiswa harus membuat kesimpulan terhadap isi bacaan untuk menjawabnya.

Berlandaskan pada hasil uji membaca (nyaring dan pemahaman) mahasiswa sampel, dapatlah dibuatkan rata-rata kompetensi sebagai berikut:

a. Skor rata-rata membaca nyaring yang dicapai sebesar 65.6.

b. Skor rata-rata membaca untuk memahami isi bacaan yang dicapa sebesar 75.1 .

c. Dari skor rata-rata yang dicapai, dapatlah disimpulkan bahwa kompetensi membaca nyaring secara rata-rata menunjukkan indikator:

\begin{tabular}{l|rr}
\hline Kurang lancar & Kurang tepat & Kurang jelas \\
\hline Artinya, & kompetensi & rata-rata \\
membaca nyaring pada & indikator \\
"kurang”. & & \\
d. Dari skor & rata-rata yang & dicapai, \\
dapatlah & disimpulkan & bahwa \\
kompetensi & membaca & untuk
\end{tabular}


memahami isi bacaan secara rata-rata menunjukkan indikator:

\begin{tabular}{|c|l|}
\hline $71-80$ & $\begin{array}{l}\text { Jawaban tepat, ditemukan } \\
\text { kesalahan tata bahasa }\end{array}$ \\
Artinya, & kompetensi rata-rata
\end{tabular}
membaca untuk memahami isi bacaan pada indikator "mampu menjawab dengan tepat tetapi ditemukan kesalahan tata bahasa”. Hal ini sesuai dengan hasil temuan bahwa yang penting menjawab, jadi bukan pada ketepatan jawaban.

\section{KESIMPULAN}

Merujuk pada permasalahan dan hasil dan pembahasan data penelitian dapatlah dipaparkan kesimpulan hasil penelitian sebagai berikut:

1. Secara umum mahasiswa Jurusan Administrasi Niaga mampu untuk mengeja berbagai huruf dalam bahasa Inggris. Hanya sekitar 18 persen mahasiswa masih belum mampu membedakan "J" vs "G”, "H”, dan "Z".

2. Secara umum mahasiswa mampu mengucapkan (melafalkan) "kata" dengan bebar, meskipun mereka kurang memperhatikan 'tekanan kata' (stressed words) ketika mengucapkan verba, nomina, adjektiva, dan adverbia.

3. Secara umum mahasiswa mampu membaca teks, tetapi pada umumnya mahasiswa tidak tahu membedakan jenis kata (parts of speech) bahasa Inggris.

4. Berkaitan dengan antonim dan sinonim, 80\% mahasiswa sampel dapat menjawab dengan benar dan 20\% masih belum mampu memberikan jawaban dengan benar.

5. Secara umum mahasiswa mampu menjawab pertanyaan essay atau teks. Artinya mahasiswa mengetahui isi bacaan atau teks, akan tetapi cara mereka menjawab tidak sesuai dengan konstruksi kalimat pertanyaannya. Mahasiswa seringkali kesulitan untuk merangkai kalimatnya sehingga mereka hanya menekankan pada adanya jawaban bukan pada ketepatan jawaban.

6. Kompetensi rata-rata membaca nyaring pada indikator "kurang”. Kompetensi rata-rata membaca untuk memahami isi bacaan pada indikator "mampu menjawab dengan tepat tetapi ditemukan kesalahan tata bahasa”

\section{DAFTAR PUSTAKA}

[1] Ahuja, Pramila dan G.C. Ahuja. 1999. How to Read Effectively and Efficiently. New Delhi. Sterling Publishing Private Limited.

[2] Anderson, Paul S. 1972. Language Skills in Elementary Education. New York: Macmillan Publishing Co. Inc.

[3] Burgess, Sally dan Katie Head. 2005. Teach for Exams. Harlow: Longman.

[4] Departemen Pendidikan dan Kebudayaan RI. 2008. Kamus Besar Bahasa Indonesia. Edisi Kelima. Jakarta: Penerbit Balai Pustaka.

[5] Echols, John M. dan Hasan Shadily. 2003. Kamus Inggris-Indonesia. Jakarta: PT Gramedia Pustaka Utama.

[6] Fahrurrozi. 2017. Peningkatan Kemampuan Membaca Permulaan Melalui Pendekatan Whole Language. Jurnal Pendidikan Usia Dini Volume 11 Edisi 1, April.

[7] Finocchiaro, Mary dan Michael Bonomo. 1973. The Foreign Language Learners: A Guide for Teacher. New York: Regents Publishing Co. Inc.

[8] Kelly, Gerald. 2003. How to Teach Pronunciation. Harlow: Longman.

[9] Tarigan, Henry Guntur. 1987. Membaca sebagai Keterampilan Berbahasa. Bandung Penerbit Angkasa. Fakultas Tarbiyah dan Ilmu Keguruan IAIN Purwokerto. 
Tabel 1. Skor dan indikator tes membaca nyaring:

\begin{tabular}{clll}
\hline \multirow{2}{*}{ skor } & \multicolumn{3}{c}{ Indikator } \\
\cline { 2 - 4 } & fluency & accuracy & clearness \\
\hline $91-100$ & Sangat lancar & Sangat tepat & Sangat jelas \\
$81-90$ & Lancar & Tepat & Jelas \\
$71-80$ & Cukup lancar & Cukup tepat & Cukup jelas \\
$61-70$ & Kurang lancar & Kurang tepat & Kurang jelas \\
$0-60$ & Tidak lancar & Tidak tepat & Tidak jelas \\
\hline
\end{tabular}

Sumber: diolah

Tabel 2. Skor dan indikator tes membaca untuk pemahaman:

\begin{tabular}{ll}
\hline skor & \\
\hline $91-100$ & $\begin{array}{l}\text { Jawaban sangat tepat disusun dalam kalimat yang sangat } \\
\text { sempurna, tidak ditemukan kesalahan huruf dan tata bahasa } \\
\text { Jawaban tepat disusun dalam kalimat yang hampir sempurna, } \\
\text { ditemukan kesalahan huruf }\end{array}$ \\
$71-90$ & Jawaban tepat, ditemukan kesalahan tata bahasa \\
$61-70$ & Jawaban tepat, ditemukan kesalahan huruf dan tata bahasa \\
$0-60$ & Jawaban tidak tepat, ditemukan kesalahan huruf dan tata \\
& bahasa
\end{tabular}

Sumber: diolah

Tabel 3. Perbandingan Jumlah Populasi dan Sampel

\begin{tabular}{lll}
\hline & Laki-laki & Wanita \\
\hline Populasi & 41 orang (17\%) & 204 orang (83\%) \\
Sampel & 14 orang (13\%) & 91 orang (87\%) \\
\hline
\end{tabular}

Sumber: diolah 


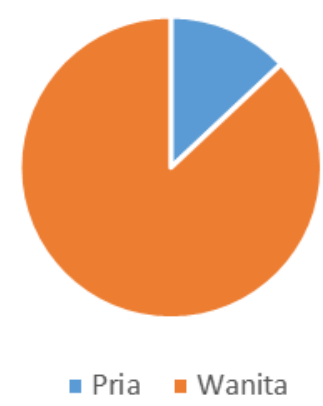

Grafik 1. Perbandingan Jumlah Sampel Berdasarkan Jenis Kelamin

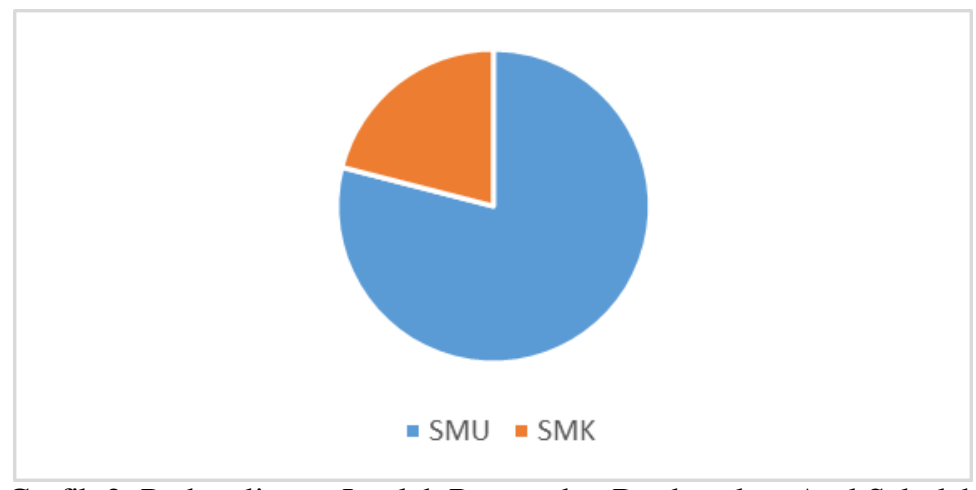

Grafik 2. Perbandingan Jumlah Responden Berdasarkan Asal Sekolah

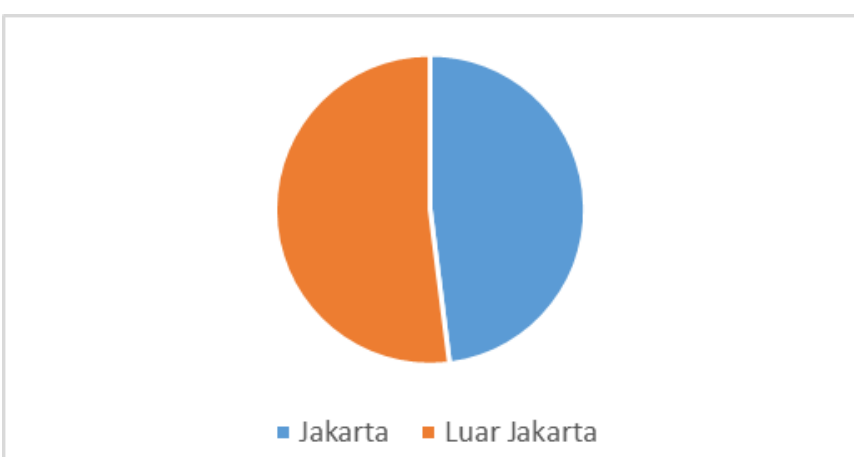

Grafik 3. Perbandingan Jumlah Mahasiswa Berdasarkan Lokasi Sekolah 

Tingkat Kemampuan Membaca ... 